\title{
МИНЕРАЛОГИЧЕСКИЕ И ГЕОХИМИЧЕСКИЕ ПАРАМЕТРЫ, ОТРАЖАЮЩИЕ ПАЛЕОЭКОЛОГИЮ ЭТАПОВ ПОЧВООБРАЗОВАНИЯ НА ЮГЕ ВОСТОЧНО-ЕВРОПЕЙСКОЙ РАВНИНЫ В ЧЕТВЕРТИЧНОЕ ВРЕМЯ
}

\author{
(C) 2020 г. А. О. Алексеев ${ }^{a,}$ *, П. И. Калинин ${ }^{a}$, Т. В. Алексеева ${ }^{a}$, В. А. Алексеева ${ }^{b}$ \\ ${ }^{a}$ Институт физико-химических и биологических проблем почвоведения РАН, Пущино, Россия \\ ${ }^{b}$ Московский государственный университет имени М.В. Ломоносова, Москва, Россия \\ *e-mail: alekseev@issp.psn.ru \\ Поступила в редакцию 27.07.2019 г. \\ После доработки 17.03.2020 г. \\ Принята к публикации 06.04.2020 г.
}

\begin{abstract}
Выполнены реконструкции динамики климатических параметров условий почвообразования в четвертичное время на юге Восточно-Европейской равнины, базируясь на изучении палеопочв как индикаторов эволюции биосферы в масштабе геологического и исторического времени. Полнота и достоверность палеогеографических реконструкций определяется выбранными объектами исследования, среди которых палеопочвы археологических памятников (курганов) степной зоны европейской части России, а также лёссово-почвенные толщи Приазовья, содержащие серии ископаемых почв плейстоцена (последние 800 тыс. лет). Для проведения количественных реконструкций параметров состояния окружающей среды использованы три независимых метода: 1) магнитный метод (магнитная восприимчивость почв), связывающий почвенную “магнитную запись” с предшествующими условиях окружающей среды степей и позволяющий получать количественные характеристики климата (атмосферные осадки) в плейстоцене и голоцене; 2) геохимический, базирующийся на эмпирических зависимостях геохимических коэффициентов выветривания, связывающих изменения валового химического состава почвенной массы и ее элементов с климатическими факторами, а также комплекс минералогических исследований; 3) методы изотопной геохимии, изотопный состав углерода, позволяющие получать информацию о климатическом режиме территории, реконструировать некоторые параметры климатических систем. На основании полученной совокупности магнитных, геохимических, изотопных параметров почв и пород предложен оптимальный вариант набора показателей для палеоклиматических реконструкций и промоделированы климатические условия (палеотемпература, палеоосадки, аридность), характерные для природной среды степей Евразии в голоцене и плейстоцене.
\end{abstract}

Ключевые слова: эволюция почв, палеопедосфера, глобальные изменения климата, магнитные свойства почв, геохимия, почвенная минералогия

DOI: $10.31857 / \mathrm{S} 2587556620040032$

\section{ВВЕДЕНИЕ}

Палеопочвы являются надежным носителем информации о палеоклимате и палеоэкологии в целом. В связи с этим в последние годы ведутся детальные разработки методических и теоретических основ изучения палеопочв как индикаторов состояния и эволюции природной среды в различные исторические и геологические эпохи, развитие палеопочвоведения идет по пути перехода из области качественного анализа к количественному подходу к палеореконструкциям. Климатические изменения являются основным фактором, влияющим на минералогический и химический состав палеопочв, что делает их незаменимым архивом, по- тенциально содержащим ответы на важные вопросы, отражающие значимые этапы эволюции биогеосферных систем в четвертичное время, базируясь на палеоаналогах. В степной зоне юга Восточно-Европейской равнины сосредоточены два типа “временных капсул" четвертичного времени, хранящих информацию о палеоэкосистемах и палеоклиматах. Во-первых, это лёссово-почвенные комплексы (Приазовье и Северный Кавказ), фиксирующие последовательность развития педосферы в интервале плейстоцена до 800 тыс. л.н. Различия в тепло- и влагообеспеченности определяли особенности процессов почвообразования, соотношение интенсивности процессов почвообразования и седиментации. Наиболее полно последова- 
тельность типов эпох почвообразования запечатлена в строении лёссово-почвенно-криогенных формаций, где обнаружены и изучены особенности почвообразования и седиментации не менее, чем семи природно-климатических макроциклов (палеомагнитная эпоха Брюнес). Внутри макроциклов выделены три главных типа эпох почвообразования: межледниковый, интерстадиальный и пленигляциальный (фазиальный) [3-5].

Во-вторых, это голоценовые палеопочвы археологических памятников, погребенные под курганными насыпями на различных временных интервалах, охватывающих средний и поздний голоцен. Палеопочвенные исследования на территории Нижнего Поволжья активно проводятся, начиная с 80-х годов XX в. Основы этих работ были заложены сотрудниками Института физико-химических и биологических проблем почвоведения РАН (Пущино): И.В. Ивановым, В.А. Демкиным, С.В. Губиным и др. [6-9, 11, 16, 19]. К настоящему времени обобщены результаты комплексного изучения широкого спектра свойств голоценовых палеопочв археологических памятников (курганов) ряда ключевых объектов степей юго-востока Русской равнины (юг Приволжской возвышенности; Северные и Южные Ергени - курганные группы на территории Ростовской области, Республики Калмыкия и Ставропольского края; Заволжья и южного Приуралья и др.). Базируясь на исследованиях большого набора почв, погребенных под разновозрастными насыпями археологических памятников степей юго-востока Русской равнины, к настоящему времени сформированы представления о климатических изменениях, коснувшихся этого региона. Реконструкции показали, что в конце IV-первой четверти III тыс. до н.э. климатические условия были ариднее современных. На рубеже IIIII тыс. до н.э. отмечается наименьшая среднегодовая норма атмосферных осадков. На I в. н.э. приходился микроплювиал, который во II-III вВ. сменился очередным засушливым периодом. В эпоху развитого средневековья (XII-XIV вв.) имел место климатический оптимум с максимумом увлажненности за последние 5000 лет. Сопоставление полученных результатов для палеопочв степей европейской части России с климатическими записями для регионов Ближнего Востока свидетельствует о синхронизации глобальных планетарных климатических колебаний [1, 8, 9, 19].

Важным этапом в палеопочвенных исследованиях явилось привлечение инструментальных минералогических и геохимических методов, а также комплекса магнитных методов. Исследование магнитных свойств и магнитной минералогии степных почв показало прямую зависимость прироста величины магнитной восприимчивости материала почвенного профиля относительно почвообразующей породы от среднегодового ко- личества осадков. Это позволило количественно рассчитать величины атмосферных осадков на изучаемой территории в прошлые исторические эпохи [1, 18, 19, 27-29]. Таким образом, был реализован новый подход для реконструкции количества атмосферных осадков в разные исторические эпохи по результатам изучения магнитной минералогии палеопочв степей в голоцене и плейстоцене [19, 27]. Анализ данных для различных регионов планеты и математическое моделирование данных, проведенное в последние годы Б. Махер с соавторами [28, 29], показали, что наибольшая статистическая зависимость между магнитными свойствами почв и среднегодовым количеством осадков фиксируется в степной зоне Русской равнины и для территории лёссового плато Китая в интервале осадков 300-700 мм/год. Это в очередной раз подтвердило правомочность этого подхода к количественным реконструкциям палеоклимата для степной зоны юга Восточно-Европейской равнины.

Перспективными методами в палеоклиматических реконструкциях являются исследования минералогических и геохимических параметров твердофазных продуктов палеопочв и четвертичных отложений [10-12, 33]. В настоящей публикации предпринята попытка демонстрации возможностей различных инструментальных методов для реконструкции динамики климатических параметров условий почвообразования в четвертичное время.

\section{ОБЪЕКТЫ ИССЛЕДОВАНИЯ И МЕТОДИКА ЭКСПЕРИМЕНТА}

Для проведения количественных реконструкций параметров состояния окружающей среды (палеотемпература, палеоосадки, аридность климата) использованы три независимых метода: 1) магнитный метод (магнитная восприимчивость почв), объединяющий почвенную “магнитную запись” с предшествующими условиями окружающей среды степей и позволяющий получать количественные характеристики климата (атмосферные осадки) в плейстоцене и голоцене; 2) геохимический, базирующийся на эмпирических зависимостях геохимических коэффициентов выветривания, связывающих изменения валового химического состава почвенной массы и ее элементов с климатическими факторами; 3) методы изотопной геохимии, изотопный состав углерода, позволяющие получать информацию о климатическом режиме территории, реконструировать некоторые параметры климатических систем. Голоценовые палеопочвы археологических памятников использовались в качестве модели для апробации и тестировании геохимических, минералогических и изотопных параметров, используемых при реконструкциях климата в дальнейшем для степ- 
ной зоны Восточно-Европейской равнины в четвертичное время.

\section{Объекты}

В качестве тестового объекта для голоценовых почв выбраны современная каштановая почва и палеопочвы второй половины голоцена - курганная группа “Авилов”. Район исследования относится к зоне сухих степей, он расположен в Волгоградской области (Иловлинский район) и приурочен к южной части Приволжской возвышенности. Исследованный педохроноряд включает почвы, погребенные $~ 5100, \sim 4900, \sim 4000, \sim 1900, \sim 1750, \sim 700$ л.н. и современную почву. Почвообразующие породы представлены покровными лёссовидными суглинками (QIII) и мелкозернистыми песками аллювиального происхождения. Среди палеопочв преобладают каштановые солонцеватые почвы, в различной степени засоленные.

Объектами исследования, фиксирующими последовательность развития педосферы в интервале плейстоцена, были опорные разрезы “Семибалки-2”, “Чумбур-Коса”, “Беглица” и др., содержащие горизонты лёссов и ископаемых почв. Объекты исследования расположены на территории Азово-Кубанской низменности на побережье Таганрогского залива. Большую часть территории занимают лёссовые аккумулятивно-эрозионные равнины [17]. Северо-Восточное Приазовье, ввиду полноты и открытости разрезов четвертичных отложений, является одним из наиболее значимых в палеогеографическом отношении районов юга Русской равнины. Береговые обнажения Таганрогского залива позволяют непрерывно прослеживать строение лёссово-почвенных комплексов на протяжении многих километров. В разрезе “Семибалки-2" представлены три региональных комплекса ископаемых ископаемых почв: воронский, инжавинский, Каменский - и три горизонта лёссов: коростылевский, борисоглебский, валдайский. В ходе экспедиционных исследований 2014 г. совместно с лабораторией А.А. Величко отобраны образцы из опорного разреза "Чумбур-Коса" (восточное побережье Таганрогского залива). В разрезе вскрыта толща плейстоценовых отложений общей мощностью 15.9 м, в которой представлены следующие палеопочвы: мезинский почвенный комплекс ( 135-117 тыс. л.н.); каменская почва ( 200-250 тыс. л.н.); инжавинская почва ( 380410 тыс. л.н.); воронская почва (500-600 тыс. л.н.). Привязка горизонтов палеопочв проведена в соответствии с хроностратиграфической схемой плейстоцена, разработанной Лабораторией эволюционной географии ИГ РАН $[4,5]$.

\section{Методы}

Химический состав образцов изучен методом рентгенфлуоресцентного анализа (SPECTROSCAN MAKC-GV) по методике измерений массовой доли металлов и оксидов металлов в порошковых пробах. Средняя проба измельчалась до пудры и помещалась в специальную кювету. Стандартная навеска была не менее 200 мг. Количественные калибровки производились с помощью комплекта Государственных стандартных образцов состава почв. Измерения показателя магнитной восприимчивости проводились в лабораторных условиях на приборе "КАРPАBRIDGE KLY-2”. Минеральный состав валовых образцов, илистой (<2 мКм) и крупной (>2 мКм) фракций был изучен методом рентгеновской дифрактометрии на дифрактометрах ДРОН-3 и Bruker - Phaser (CuKa излучение). Рентгеновская диагностика глинистых минералов базировалась на результатах следующих тестов: $\mathrm{Mg}$ - форма в воздушно-сухом состоянии; $\mathrm{Mg}$ - форма, насыщенная этиленгликолем в течение 24 ч; $\mathrm{Mg}-$ форма, прокаленная до $350^{\circ} \mathrm{C}$ в течение 2 ч; $\mathrm{Mg}-$ форма, прокаленная до $550^{\circ} \mathrm{C}$ в течение 2 ч; и ряд других стандартных тестов. Структурные особенности захороненного органического вещества (OВ) изучены методом твердофазной ЯМР-спектроскопии на ядрах ${ }^{13} \mathrm{C}$ (Bruker Avance NMR 400 $\mathrm{MHz}$. Изотопный состав углерода органического вещества почв изучен методом масс-спектрометрии с использованием аналитического ЕА-CFIRMS комплекса, состоящего из элементного анализатора Flash 1112, изотопного масс-спектрометpa Delta V Advantage и интерфейса ConFlo III. Навески проб для анализа взвешивались на весах Mettler Toledo XP26, масса навесок находилась в пределах 20-30 мг. Для обеспечения метрологического контроля использовался международный стандарт МАГАТЭ USGS40. Определение изотопного состава углерода каждой пробы выполнялось в двухкратной аналитической повторности. Подготовка образцов для морфоскопического изучения песчаных зерен с помощью растрового электронного микроскопа осуществлялась по принятой в мировой практике методике [2, 36]. Форма и характер поверхности кварцевых зерен изучались для фракции среднего (0.25-0.5 мм) песка с использованием сканирующего электронного микроскопа SEM TESCAN VEGA 3 LMU. Из каждого образца исследовалось по 25 случайно отобранных зерен кварца. При описании зерна оценивались три группы признаков: 1) общие морфологические особенности (форма зерна, характер поверхности зерна); 2) элементы поверхности, образованные в результате механического воздействия на зерна; 3) текстуры, имеющие химическое происхождение. 


\section{РЕЗУЛЬТАТЫ И ОБСУЖДЕНИЕ}

Для проведения количественных реконструкций параметров состояния окружающей среды (палеотемпература, палеоосадки, аридность климата), как отмечалось выше, были использованы различные методы и подходы.

Магнитные свойства степных почв связаны с биоклиматическими условиями. Содержание почвенного (биогенного) магнетита является “магнитной записью”, которая может сохранять информацию о предшествующих условиях окружающей среды степей и позволяет получать количественные характеристики климата (атмосферные осадки) в плейстоцене и голоцене $[1,18$, $19,27]$. Для палеоэкологических реконструкций нами в качестве оптимального показателя и наиболее легко получаемого технически выбрана величина прироста магнитной восприимчивости в почвенном профиле относительно материнской породы.

Среднегодовая норма атмосферных осадков (мм) (степная зона европейской части России) определяется следующим уравнением:

$$
\text { MAP_MS }=86.4 \operatorname{Ln}\left(\mathrm{X}_{\mathrm{B}}-\mathrm{X}_{\mathrm{C}}\right)+90.1,
$$

где $\left(\mathrm{X}_{\mathrm{B}}-\mathrm{X}_{\mathrm{C}}\right)-$ прирост магнитной восприимчивости в результате почвообразования.

Для территории лёссового плато Китая ранее были получены аналогичные эмпирические зависимости [29].

Геохимический подход базируется на эмпирических зависимостях коэффициентов выветривания, связывающих изменения валового химического состава почвенной массы и ее элементов с климатическими факторами (палеоосадки МАР, палеотемпературы - МАТ).

Геохимические коэффициенты предшествующих исследований (CIA, PWI, Rb/Sr, Ba/Sr):

$$
\begin{gathered}
\mathrm{CIA}= \\
=\left[\mathrm{Al}_{2} \mathrm{O}_{3} /\left(\mathrm{Al}_{2} \mathrm{O}_{3}+\mathrm{CaO}^{*}+\mathrm{Na}_{2} \mathrm{O}+\mathrm{K}_{2} \mathrm{O}\right)\right] \times 100[30] .
\end{gathered}
$$

Отражает соотношение первичных и вторичных минералов в валовом образце. Может быть использован как климатический показатель. Невыветрелые породы характеризуются значениями CIA 50 ед., тогда как сильно выветрелые их разновидности имеют СІА до 100 ед., в почвах этот коэффициент отражает в первую очередь степень преобразованности вторичных глинистых минералов илистой фракции.

PWI (палеопочвенный индекс выветривания) используется как климатический показатель для получения информации о палеотемпературах [22]:

$$
\begin{gathered}
\text { PWI }= \\
=[(4.20 \mathrm{Na})+(1.66 \mathrm{Mg})+(5.54 \mathrm{~K})+(2.05 \mathrm{Ca})] \times 100 .
\end{gathered}
$$

$\mathrm{Rb} / \mathrm{Sr}$ - коэффициент предложен как разница в устойчивости различных минералов к выветриванию, а именно слюд и калиевых полевых шпатов, с которыми в ассоциации находится $\mathrm{Rb}$, и карбонатов, с которыми ассоциирует $\mathrm{Sr}$ [23]; $\mathrm{Ba} / \mathrm{Sr}$ - характеризует гидротермические условия осадконакопления, в частности, процесс выщелачивания [32, 33]. Ва находится в ассоциации с калиевым полевым шпатом и выносится из почв слабее $\mathrm{Sr}$, который ассоциирует с карбонатами.

Подробный анализ использования предложенных показателей и ряда других, а также обоснование этого подхода представлен в ряде публикаций [11, 33, 34].

Калибровки, полученные на основании анализа современных почв различных климатических зон в основном для территории Северной Америки, выявили следующие зависимости:

$$
\begin{gathered}
\text { MAP }=221.1 \mathrm{e}^{\wedge} 0.0179(\mathrm{CIA}-\mathrm{K})[34], \\
\text { MAT }=-2.74 \ln (\mathrm{PWI})+21.39[22] .
\end{gathered}
$$

Также нами используется для количественных реконструкций обнаруженная зависимость с уровнем атмосферных осадков концентрации $\mathrm{Rb}$ в гумусовых горизонтах погребенных почв сухостепной зоны России, относительно фоновых значений, характерных для пород данного региона.

Методы изотопной геохимии также позволяют нам получать информацию о климатическом режиме территории, реконструировать некоторые параметры климатических систем $[15,16,21,24$, $31,39,40]$.

Сумму среднегодовых атмосферных осадков (МАР) возможно оценить, используя эмпирическую зависимость \% С4-растений-атмосферные осадки, полученную в наших предшествующих исследованиях $[15,16]$. Кроме того, поскольку гумус наследует изотопный состав растительности, то по значениям $\delta^{13} \mathrm{C}$ гумуса можно выяснить, какие растения преобладали в составе растительности в то или иное время. С4-растения более конкурентоспособны в аридных условиях, что позволяет оценить степень аридности по доле С4растений в экосистемах. Чем “тяжелее" изотопный состав углерода, тем больше в составе растительности присутствовало С4-растений, тем ариднее был климат. Очень важным для палеореконструкций является “время отклика" изотопного состава углерода гумуса на изменение растительности. Оно составляет всего несколько десятков лет. Таким образом, изучая изотопный состав органического вещества погребенных под археологическими памятниками почв, мы имеем возможность реконструировать природные условия времени, непосредственно предшествующего его сооружению. И даже краткосрочные изменения 

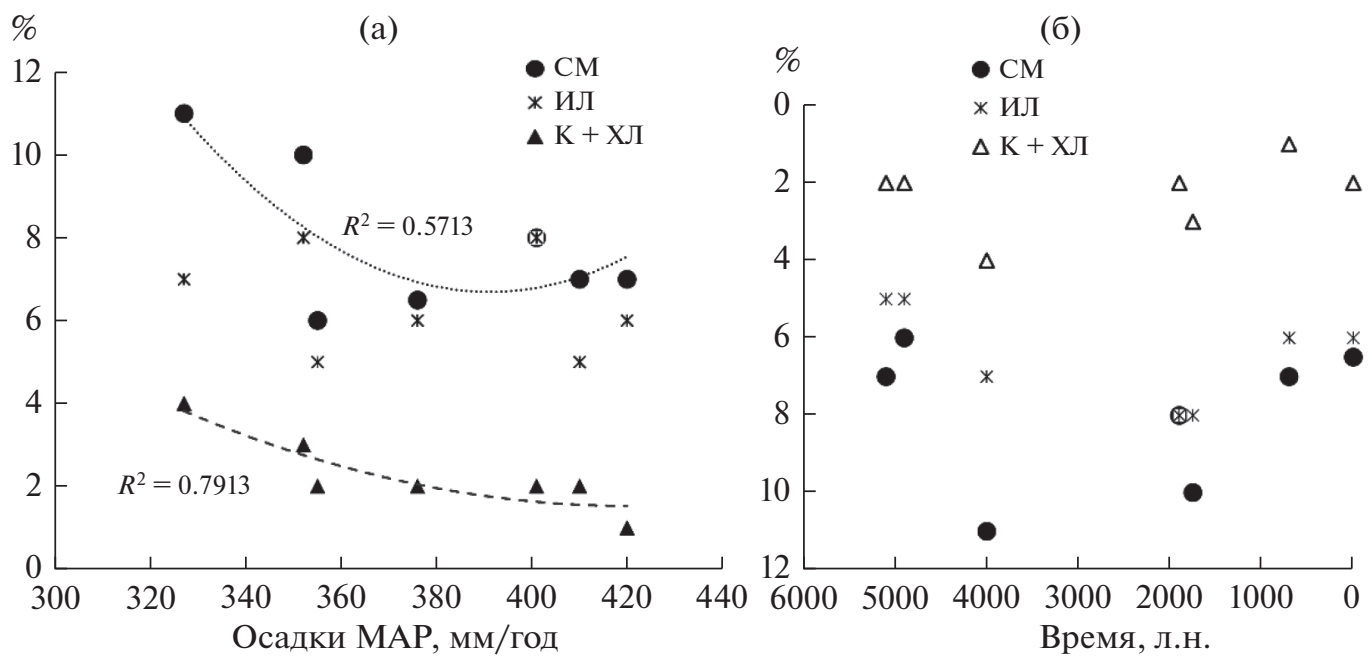

Рис. 1. (а) Связь глинистой минералогии палеопочв хроноряда “Авилов” с реконструированными изменениями среднегодовых атмосферных осадков по магнитным свойствам палеопочв; (б) связь глинистой минералогии палеопочв с возрастом погребения почв. СМ - смектит; ИЛ - иллит; К + ХЛ - каолинит + хлорит.

природной среды имеют шанс быть зафиксированы при подобных исследованиях.

Предлагается рядом авторов также проведение реконструкций среднегодовой температуры по изотопному составу углерода (ИСУ) гумуса [31], позволяющие оценить температуры середины лета. Эта эмпирическая зависимость успешно использовалась при реконструкции климата семиаридных территорий.

Перечисленные выше подходы были применены к изучаемым палеопочвам и отложениям.

\section{Голоценовый хроноряд палеопочв}

На основании ранее полученных зависимостей величины прироста магнитной восприимчивости от количества атмосферных осадков $[1,19,27]$ был рассчитан уровень атмосферной увлажненности на исследуемой территории, который составил 330-420 мм/год. При этом наименьшее количество осадков характерно для почвы, погребенной 4000 л.н. (около 330 мм/год). Максимальная степень увлажненности отмечается для почв, погребенных 5100, 1900 л.н., и почв средневековья (400-420 мм/год). В дальнейшем полученные параметры были использованы для интерпретации процессов преобразования минеральной массы почв и органического вещества почв в связи с вариациями климатических условий в позднем голоцене (рис. 1).

Определенные климатические колебания нашли свое отражение в изменении минералогического состава палеопочв (см. рис. 1a). В ходе изучения илистой фракции гор. A1 и В1 разновозрастных палеопочв были выявлены следующие особенности. В профилях изученных почв смек- титовая фаза представлена смешанослойным иллит-смектитом, его содержание убывает к гор. А1, где составляет от 30 до 51\%, тогда как содержание гидрослюды возрастает в том же направлении и изменяется в пределах от 35 до 50\%. Для почв, имеющих признаки солонцеватости, максимальное содержания смектитовой фазы отмечается в солонцовых В1-горизонтах почв, погребенных $5100,4900,700$ л.н. и современной почве, достигая 67\%. Стоит отметить, что максимально процессы преобразования минеральной массы почв затрагивают 2 верхних горизонта (верхние $30 \mathrm{~cm}$ профиля). Здесь, помимо описанных выше процессов преобразования, отмечается разрушение хлоритовой фазы. Данное явление не характерно для почв, формирующихся в условиях наиболее аридного климата - 4000 и 1750 л.н. Для них характерно сохранение хлоритов в пределах всего профиля, включая и гор. А1. Климатические изменения являются определяющими в интенсивности минералогических преобразований по сравнению с длительностью выветривания (см. рис. 1б).

Указанные изменения также фиксируются в геохимических коэффициентах в связи с их чувствительностью к процессам преобразования минералогического состава степных почв. Значения СІА для валовых образцовов почв изменяются в пределах от 25 до 70, Rb/Sr - от 0.20 до 0.62 , $\mathrm{Al}_{2} \mathrm{O}_{3} /\left(\mathrm{CaO}+\mathrm{MgO}+\mathrm{K}_{2} \mathrm{O}+\mathrm{Na}_{2} \mathrm{O}\right)$ от 0.26 до 1.41. Во всех случаях максимальные величины индексов отмечаются для горизонтов А1 почв влажных климатических эпох, погребенных 5100, 1900, 700 л.н. и современной каштановой почвы. Для них значения CIA варьируют от 55 до $65, \mathrm{Rb} / \mathrm{Sr}-$ от 0.51 до 0.62. Минимальные значения характер- 
ны для почв аридных условий формирования (погребенных 4000 и 1750 л.н.) - СІА - от 44 до 50, $\mathrm{Rb} / \mathrm{Sr}$ - от 0.37 до 0.48 .

В случае илистой фракции возможно применение геохимических индексов $-\mathrm{Rb} / \mathrm{Sr}$ и $\mathrm{Ba} / \mathrm{Sr}$. При изучении коэффициента $\mathrm{Ba} / \mathrm{Sr}$, характеризующего гидротермические условия, в частности, процесс выщелачивания, повышенные значения наблюдаются как для A1, так и для В1-горизонтов почв и изменяются в пределах от 2.57 до 7.34. Максимумы, как и в случае коэффициента $\mathrm{Rb} / \mathrm{Sr}$, характерны для гор. А1 почв, формировавшихся под влиянием гумидных условий (от 6.71 до 7.34). Значения коэффициента $\mathrm{Rb} / \mathrm{Sr}$ для изученных почв находятся в интервале от 0.31 до 1.97. При этом максимальные значения отмечаются для гор. А1 почв влажных климатических эпох (погребенных 5100, 1900 л.н. и современной почвы) и составляют 1.50-1.97. Минимальные значения характерны для почв, погребенных 4000 и 1750 л.н. $-0.98-1.09$. Для почвообразуюшей породы значение $\mathrm{Rb} / \mathrm{Sr}$ составляет от 0.46 до 0.74 .

Мы считаем, что Rb накапливается в верхних горизонтах почв в результате выветривания глинистых минералов, в частности смектита, в результате чего в гумусовом горизонте остаются более устойчивые к выветриванию гидрослюды, такие как иллит, в которые в виде изоморфной примеси входит $\mathrm{Rb}$, при этом биологические факторы, так же, как и испарительная концентрация, не играют существенной роли в его накоплении. Этот показатель может рассматриваться по аналогии с иллит-смектитовыми показателями, предложенными для почв автоморфного ряда, сформировавшихся на лёссах и лёссовидных отложениях.

Проведена отработка методики расшифровки информации, сохраняющейся в органоминеральных комплексах палеопочв. Выполнено изучение ОВ в валовых образцах и в составе илистой фракции фоновых почв и палеопочв голоценового хроноряда методом твердофазной ${ }^{13} \mathrm{C}$-ЯМР спектроскопии.

Содержание органического углерода в А1-горизонтах изученных почв составляет $0.59-2.01 \%$. По профилю оно изменяется в широких пределах от 0.29 до $1.65 \%$. Изучение ОВ почв показало, что содержание органического углерода (OC) в валовом образце современной почвы составляет $2.01 \%$, азота $(\mathrm{N})-0.17 \%$; в илистой фракции $\mathrm{OC}=2.89 \%, \mathrm{~N}=0.37 \%$. Для валовых образцов почв характерно уменьшение содержания ОС от 1.14 до $0.59 \%, \mathrm{~N}$ от 0.08 до $0.05 \%$. Илистые фракции всех изученных почв обогашены ОС и $\mathrm{N}$ по сравнению с валовыми образцами. Изучение состава и характеристик ОВ показало, что потери ОС и $\mathrm{N}$ валовых образцов почв коррелируют со временем, прошедшим с момента погребения почвы, поведение $\mathrm{C}_{\text {орг }}$ в составе илистой фракции определяется степенью увлажненности.

Метод спектроскопии ЯМР ${ }^{13} \mathrm{C}$ позволяет получать уникальную информацию о доминирующих типах углерод-углеродных связей и их пространственном расположении. На сегодняшний день имеется достаточно полная классификация химических сдвигов ядер атомов углерода по типам связей, позволяющая идентифицировать основные структурные фрагменты многокомпонентных смесей органических молекул [37]. ${ }^{13} \mathrm{C}$ ЯМР спектры валового образца гор. А1 современной почвы и его илистой фракции имеют сходные характеристики: преобладают О-алкилы - 35\%. Содержание алифатических структур составляет около 25-27\%, ароматических 17-19\% и карбоксильных групп 11-14\%. ОВ в составе илистой фракции погребенных почв, формировавшихся в условиях гумидного климата (погребенных 5100, 700 л.н.), характеризуется близким составом, но здесь по сравнению с илистой фракцией современной почвы несколько сокращается содержание алкилов, а содержание ароматических структур и карбоксильных групп возрастает. ${ }^{13} \mathrm{C}$-ЯМР спектр илистой фракции почвы аридного типа (погребенной 4000 л.н.) резко отличен. Для этого образца характерно низкое содержание ароматических структур (13\%) и преобладание алифатических (30\%).

Анализ параметров ЯМР спектров органоминеральных комплексов илистых фракций погребенных и современных почв продемонстрировал наличие прямых корреляций качественных характеристик (отношение содержания алкилов, Оалкилов с ароматичностью) с вариациями климатических условий голоцена (рис. 2a). Следует подчеркнуть, что значимость получаемых зависимостей для илистой фракции существенно выше по сравнению с валовым образцом. Изменения изотопного состава ОВ в илистой фракции палеопочв изученного хроноряда отражают динамику климатических условий степей в голоцене и позволяют определить различие в соотношении групп C3/C4-растений в связи с изменением климата. Таким образом, подтверждена возможность использования изотопного состава углерода органоминеральных комплексов (илистая фракция палеопочв) для палеореконструкций (рис. 2б).

Кроме того, для изученного хроноряда почв проведена апробация возможности количественной оценки палеотемператур для голоценовых палеопочв на основе геохимических индексов (PWI) [22]. Полученные результаты коррелируют с записями палеотемператур для голоцена по ледникам Гренландии [20]. Таким образом, данный инструмент позволит в дальнейшем рассчитывать гидротермический показатель индекс аридности и оценить детально сдвиги границ климатических 

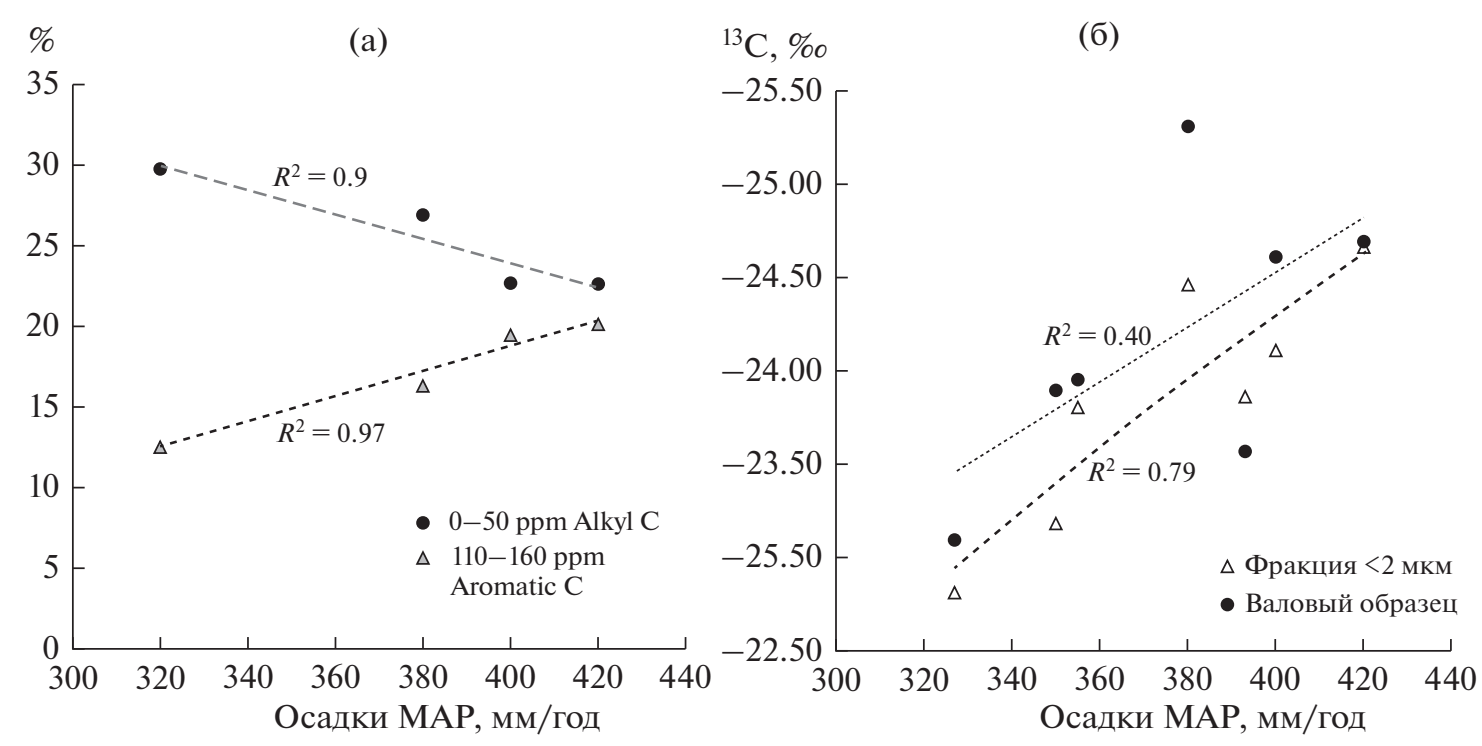

Рис. 2. (а) Изменение качественных характеристик органического вещества палеопочв по данным ЯМР спектроскопии в зависимости от климатических факторов (0-50 ppm - алифатические структуры; $110-160$ pрm - ароматические структуры); (б) изменение изотопного состава углерода органического вещества почв в зависимости от климатических факторов.

зон на протяжении позднего голоцена на юге Восточно-Европейской равнины.

\section{Лёссово-почвенные комплексы Приазовья}

В качестве примера приведем детальные климатические реконструкции для разреза "Семибалки-2” с использованием параметров состояния твердой фазы палеопочв (рис. 4).

Средние значения показателя удельной магнитной восприимчивости в лёссах составляют порядка $32\left(* 10^{-8} \mathrm{M}^{3} / \mathrm{кг}\right)$, в почвенных горизонтах порядка 62. Это говорит о том, что условия почвообразования способствовали формированию ферримагнитных минералов. Максимальные значения фиксируются в Воронской почве $~ 77$ и уменьшаются в почвенных горизонтах вверх по разрезу: $\sim 72$ в Инжавинской, $\sim 51$ в Каменской почве.

Реконструированный по магнитным данным среднегодовой уровень атмосферных осадков, существовавший на протяжении формирования лёссово-почвенного комплекса "Семибалки-2", составлял в эпохи оледенений в среднем 290 мм/год. В более теплые и влажные периоды межледниковий, во время которых формировались почвенные комплексы, среднегодовой уровень атмосферных осадков увеличивался в среднем до 580 мм/год. Максимальные значения фиксируются в Мучкапское межледниковье (580 мм/год) и последовательно снижаются в Лихвинское (560 мм/год) и Каменское (530 мм/год). Если рассматривать процентное отклонение этих показателей от совре- менной голоценовой почвы, отмечается уменьшение уровня атмосферной увлажненности до $40 \%$ в ледниковые периоды и увеличение до 5\% в межледниковые эпохи. В целом, исходя из полученных значений, можно заключить, что по магнитным параметрам в течении плейстоцена сохраняется тренд на аридизацию (рис. 3).

По показателю СІА породы, слагающие разрез “Семибалки-2", являются слабовыветрелыми [35]. Среднее значение CIA в лёссовых горизонтах составляет 51, в почвенных комплексах 64. Показателем СІА порядка 70 характеризуются отложения, находящиеся на глубине 8.45-8.75 м. Эти слои соответствуют Воронскому педокомплексу, сформированному в Мучкапское межледниковье. Для этих отложений отмечается повышение значений показателей выветривания и выщелачивания (СIA 67-70, $\mathrm{Rb} / \mathrm{Sr} \sim 0.4-0.5$, $\mathrm{Ba} / \mathrm{Sr} \sim 1.7-2.1)$. В Инжавинской почве, сформированной в Лихвинское межледниковье, наблюдается увеличение показателя СІА до 73, что соответствует достаточно выветрелым отложениям, формировавшимся в условиях относительно влажного и теплого климата, а также коэффициентов выветривания $\mathrm{Rb} / \mathrm{Sr} \sim 0.4$. Некоторым увеличением коэффициента СIA (порядка 62-66) характеризуется слой, залегающий на глубине 2.6-3.6 м. Он сложен темно-коричневым суглинком и является сформированной в Чекалинское межледниковье Каменской почвой.

Значения коэффициента CIA $\leq 50$ соответствуют холодным этапам лёссонакопления. CIA $=47$ наблюдается в сложенном серо-коричневым 


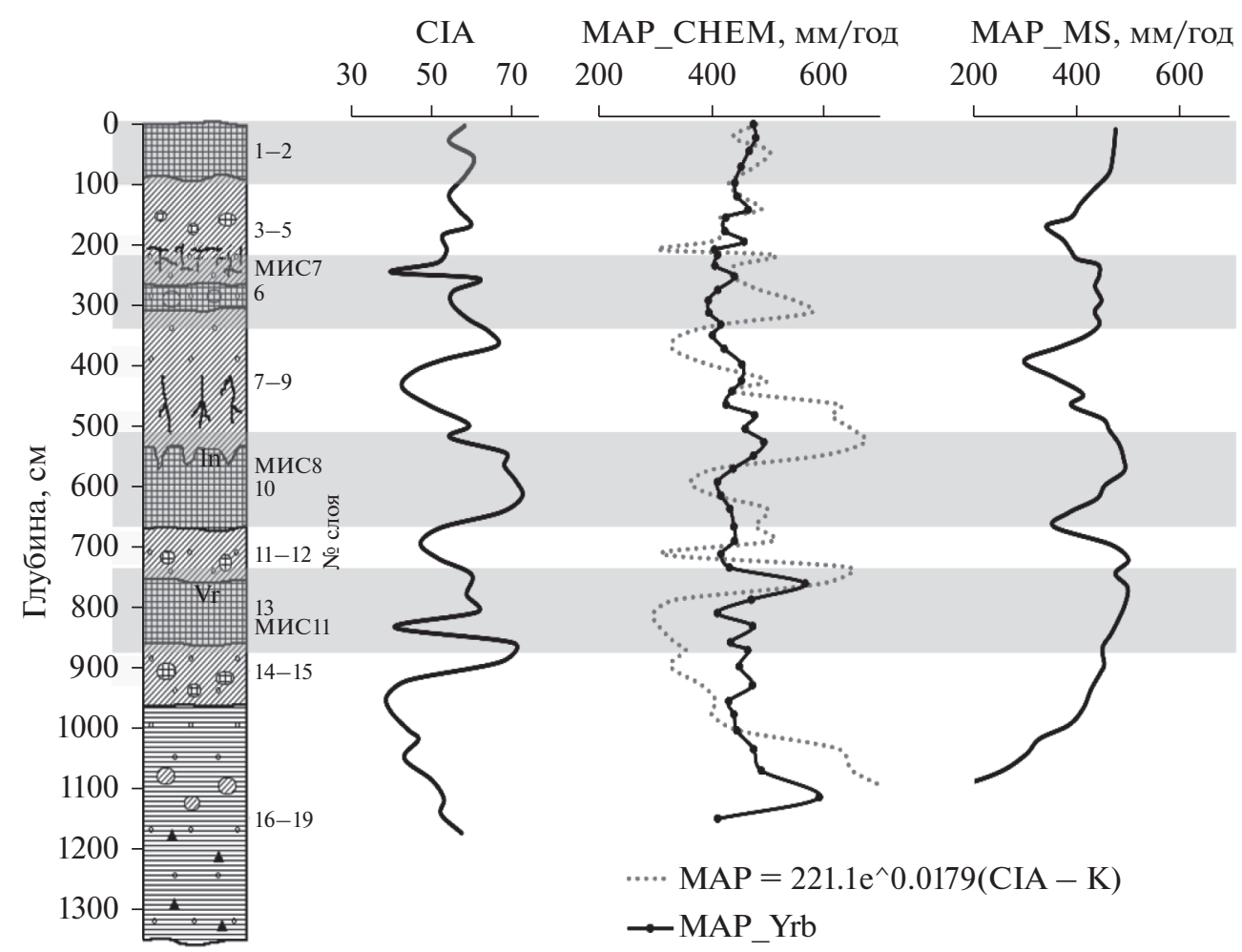

Рис. 3. Палеоклиматические реконструкции среднегодового уровня атмосферных осадков на различных этапах исследуемого хроноинтервала для разреза “Семибалки-2” с помощью геохимических параметров и магнитных свойств почв и лёссов.
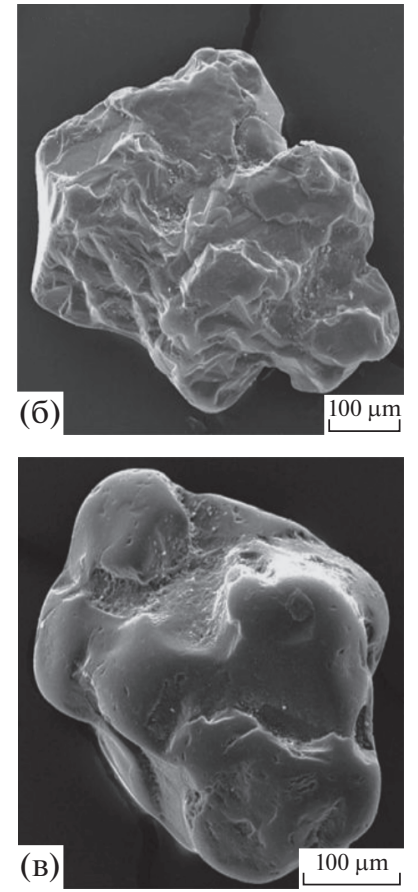
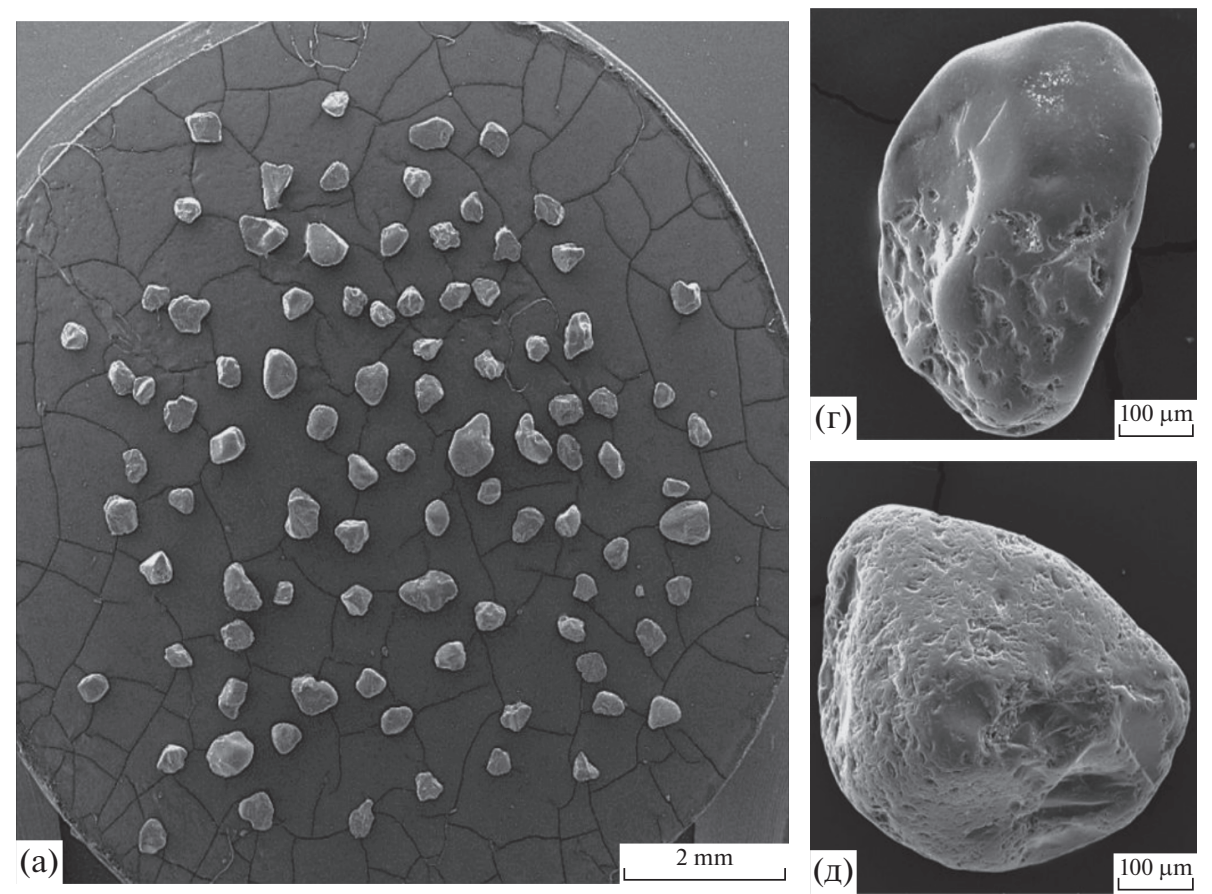

Рис. 4. Морфоскопические особенности зерен кварца фракции 0.25-0.5 мм из отложений разреза Чумбур-Коса, Ростовская область: (а) ансамбль частиц различной формы (окский лёсс); (б) кварцевое зерно элювиальной группы (инжавинская почва); (в) кварцевое зерно элювиальной группы с чертами водного переноса (днепровский лёсс); (г) кварцевое зерно, сильно преобразованное в ходе транспортировки в водной среде (инжавинская почва); (д) кварцевое зерно, преобразованное в ходе активного водного переноса, со следами криогенного воздействия (борисоглебский лёсс). 
суглинком слое Коростылевского лёсса, расположенном на глубине 6.8-7.1 и представляющий собой отложения Коростылевского лёсса. Значения коэффициентов выветривания: $\mathrm{Rb} / \mathrm{Sr}$ 0.3 и Ba/ $\mathrm{Sr} \sim 1.8$. Выше по разрезу на глубине 4.4 м залегает слой, сложенный коричнево-палевым суглинком, для которого характерно значение показателя CIA порядка 43, что является характерным для слабо выветрелых пород. Этот слой относится к отложениям Борисоглебского лёсса. В нижней части слоя, залегающего на глубине 2.5 м и сложенного плотным коричневым суглинком, отмечается значение коэффициента СIA порядка 40. Эти отложения диагностируются как Валдайский лёсс (Валдайское оледенение).

На рис. 4 приведены данные расчета МАР с использованием геохимических показателей. В целом, показатели МАР с использованием индекса CIA, по-видимому, завышают значения осадков, т.к. по морфотипическим признакам погребенных почв в среднем и позднем плейстоцене на исследуемой территории преобладали степные ландшафты, для формирования которых необходимы более низкие значения осадков.

Рассчитанное с помощью показателя YRb количество осадков значительно ниже. Средние значения для ледниковых эпох составляют около 320 мм/год, для межледниковых периодов 390 мм/год. Максимальное значение фиксируется в Мучкапское межледниковье $\sim 40$ мм/год.

По показателям МAP 1 и YRb фиксируется тренд на аридизацию и уменьшение количества атмосферных осадков от 570-520 мм/год в Мучкапское межледниковье до 440-490 мм/год в Каменское. Эти значения сопоставимы с реконструкциями осадков в межледниковые эпохи по показателю магнитной восприимчивости. Таким образом, для межледниковых эпох плейстоцена были характерны более влажные, чем современные, условия. В ледниковые периоды количество атмосферных осадков уменьшалось на 20-40\% относительно современных значений. Схожий результат был получен и для других изученных разрезов в регионе.

Для опорных разрезов Чумбур-Коса, Беглица, содержащих серии лёссов и ископаемых почв, наиболее полно отражающих четвертичную историю юга Восточно-Европейской равнины, проведены детальные исследования глинистой минералогии с целью апробации новых параметров для палеореконструкций (минералогические индексы - иллит/хлорит и иллит/смектит). Для почвенных горизонтов отмечается увеличение этих индексов по сравнению с лёссами (детально данные не приводятся). Интенсивность процесса иллитизации определяется климатическими факторами. Полученные результаты согласуются с гео- химическими данными и реконструкциями, базирующимися на магнитной минералогии палеопочв.

С целью реконструкции условий лёссонакопления и формирования погребенных почв ключевого разреза Чумбур-Коса проведена также морфоскопия песчаных кварцевых зерен методом растровой электронной микроскопии. В целом по разрезу преобладают зерна округлой формы (III-IV классы окатанности по А.В. Хабакову [13]), доля которых колеблется от 54 до 68\%. Доля средне окатанных частиц (II класс окатанности) составляет $28-46 \%$, а слабо окатанные песчинки угловатой формы (I класс окатанности) встречаются в единичных случаях (0-8\%). Соответственно, коэффициент окатанности выборки частиц варьирует от 64 до 70\%, причем средние значения данного коэффициента несколько ниже для отложений лёссов, чем для материала погребенных почв (66 и 68\% соответственно). Это можно объяснить более интенсивно протекающими в почвах процессами химического выветривания, что приводит к сглаживанию контуров частиц за счет формирования на поверхности пленок кремнезема.

Во всех изученных образцах преобладают хорошо окатанные кварцевые зерна с гладкой поверхностью, специфическая комбинация элементов поверхности которых характеризует частицы, испытавшие интенсивную обработку в водной среде (рис. 4г-4д). Доля таких зерен по разрезу составляет 56-84\%, лишь в отложениях Мезенской почвы опускаясь до 44\%. Весомая доля частиц (12-36\%) несет следы незначительного преобразования в водной среде: зерна имеют преимущественно полуугловатую форму и распространение характерных элементов лишь на выпуклых частях зерен (рис. 4в). В единичных случаях встречаются угловатые частицы, облик которых характерен для продуктов разрушения подстилающих коренных пород (рис. 4б), а также зерна кварца, в сильной степени измененные процессами химического выветривания. Следы незначительной эоловой обработки в виде мелкоямчатого микрорельефа на выпуклых частях зерен наблюдаются лишь на 4-8\% частиц в ряде образцов лёссов и погребенных почв.

Во всех изученных образцах присутствуют кварцевые зерна со следами криогенного выветривания в виде относительно “свежих" наложенных сколов, борозд и трещин, образующихся в результате комплексного воздействия процессов криогенного выветривания, приводящего к раскалыванию [14, 25, 36, 38]. Содержание зерен с криогенными текстурами поверхности (см. рис. 4д) колеблется от 20 до $56 \%$ и в целом увеличивается к нижней части разреза. При этом доля частиц с криогенными чертами поверхности в погребенных почвах немного выше, чем в лёссах (43 и $40 \%$ соответственно). Процессы химического 


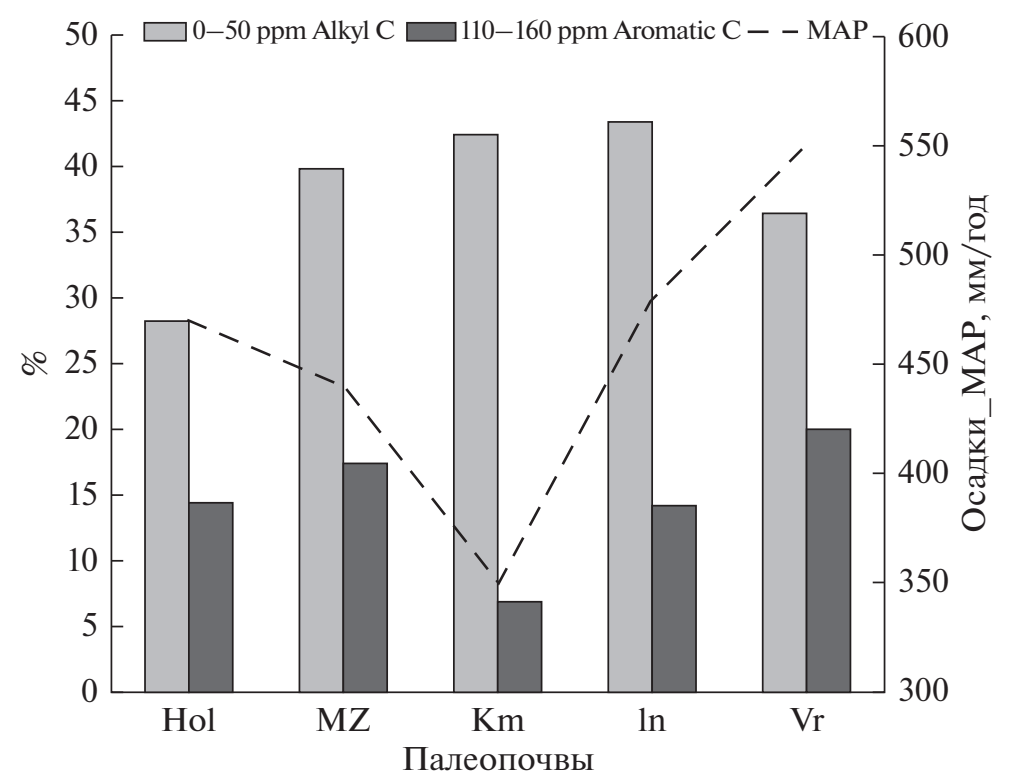

Рис. 5. Изменение качественных характеристик органического вещества палеопочв разреза Чумбур-Коса (илистая фракция) по данным ЯМР спектроскопии в зависимости от климатических факторов (0-50 ррт алифатические структуры; 110-160 ppm ароматические структуры).

выветривания песчаных частиц представлены в виде как следов травления ранее сформированных элементов поверхности (например, более глубокая проработка серповидных желобков, см. рис. 4д), так и в виде “изъеденных" растворением участков зерен (см. рис. 4г). Содержание зерен со следами химического выветривания довольно велико во всех изученных образцах (36-48\%) и увеличивается в нижней части разреза (до 56-72\%), что может быть связано с более длительным временем воздействия.

Анализ морфоскопии зерен кварца разреза Чумбур-Коса позволяет говорить, что абсолютно преобладают кварцевые зерна, в той или иной степени испытавшие перенос в водной среде; суммарная доля их в среднем составляет 89\%. Высокая степень окатанности частиц и плотность специфических элементов на их поверхности указывает на то, что коренным источником, вероятно, являются прибрежно-морские отложения. При формировании отложений лёссовых толщ и разделяющих их горизонтов погребенных почв участвовал один основной источник поступления вещества. Слабая выраженность эоловой обработки указывает на то, что это был источник ближнего сноса. Отсутствие четко выраженной динамики в распределении кварцевых зерен того или иного типа свидетельствует о многократном переотложении материала. Высокая встречаемость элементов травления и химического растворения свидетельствует о длительности и интенсивности процессов химического выветрива- ния. Вместе с тем, присутствие криогенных элементов говорит о наличии мерзлоты.

В дополнение для разреза Чумбур-Коса, помимо детальной характеристики минеральной матрицы ископаемых почв изучено захороненное почвенное ОВ с использованием традиционных для почвоведения химических методов и комплекса инструментальных физико-химических методов его исследования, включая твердофазную ${ }^{13} \mathrm{C}$ ЯМР спектроскопию. Целью детального исследования состава захороненного ОВ является изучение древнего гумуса и форм его захоронения в ископаемых почвах, выявление его особенностей в зависимости от состава растительности, типа почвообразования и состава минеральной матрицы палеопочв, а также изучение цикла органического углерода в масштабе геологического времени. Анализ ЯМР спектров органоминеральных комплексов илистых фракций погребенных почв лёссово-почвенного комплекса, как и в случае с голоценовым хронорядом, продемонстрировал наличие корреляций качественных характеристик с вариациями климатических условий (рис. 5).

Проведена реконструкция климатических факторов по ИСУ гумуса. Для илистой фракции отмечаются значимые изменения в изотопных данных $\delta^{13} \mathrm{C}$, отражающих климатические факторы МАТ (температуры) и МАР (осадки). Проведены пробные реконструкции среднегодовой 
температуры по ИСУ гумуса. Данный подход позволяет оценить температуры середины лета:

$$
\operatorname{MAT}(J)=\left[0.685\left(\delta^{13} \mathrm{C}\right)+34.9\right][31] .
$$

Для разреза Чумбур-Коса. $\delta^{13} \mathrm{C}$ ИСУ палеопочв и лёссов лежит в интервале - 27.2-25.52\%о, что свидетельствует о преобладании С3-растений. Для всех лёссов значения $\delta^{13} \mathrm{C}$ облегчаются в интервале $1.5-2 \%$ по сравнению с палеопочвами, что подтверждает понижение среднегодовой температуры в период лёссонакопления. Полученные результаты свидетельствуют об информативности изотопного состава углерода органо-минеральных комплексов (илистая фракции палеопочв) для палеореконструкций, но требуют дополнительных исследований.

\section{ЗАКЛЮЧЕНИЕ}

Таким образом, на основании полученной совокупности магнитных, минералогических, геохимических и изотопных параметров почв и пород выделяется оптимальный вариант набора показателей для палеоклиматических реконструкций. Применение разных методов дополняет и подтверждает полученные результаты, динамика климата существенным образом сказывается на состоянии почв степной зоны и находит отражение в формировании, исчезновении или степени выраженности их свойств и признаков. Проведение детального минералогического анализа палеопочв и их илистых фракций и органо-минеральных комплексов, поддержанное изучением вариаций биофильных и литофильных элементов, существенно увеличивает информативность геохимических показателей для получения информации о палеоклиматических условиях.

Базируясь на изучении геохимических, магнитных и минералогических параметрах палеопочв по хроноряду палеопочв голоцена и ключевым разрезам лёссово-почвенной серии Приазовья (Чумбур-Коса, Семибалки-2, др.), получены количественные параметры состояния окружающей среды (палеотемпература, палеоосадки, аридность климата). На территории Приазовья в плейстоцене существовал направленный сдвиг гидротермического режима межледниковых эпох от условий с более высокой влагообеспеченностью к условиям роста аридизации. Наиболее гумидные условия на исследуемой территории существовали в период Мучкапского межледниковья (500600 мм/год), наиболее аридные - в эпоху Каменского межледнековья (400-500 мм/год). В ледниковые эпохи на территории Приазовья в среднем в год выпадало 300-400 мм осадков.

Анализ морфоскопии зерен кварца разреза Чумбур-Коса позволяет говорить, что абсолютно преобладают кварцевые зерна, в той или иной степени испытавшие перенос в водной среде. Высокая степень окатанности частиц и плотность специфических элементов на их поверхности указывает на то, что коренным источником, вероятно, являются прибрежно-морские отложения. Слабая выраженность эоловой обработки указывает на то, что это был источник ближнего сноса. Четкой разницы в морфоскопии кварцевых зерен из отложений лёссовых толщ и разделяющих их горизонтов погребенных почв не наблюдается; можно сказать, что при формировании этих отложений участвовал один основной источник поступления вещества. Отсутствие четко выраженной динамики в распределении кварцевых зерен того или иного типа свидетельствует о многократном переотложении материала.

Следует отметить, что калибровки, используемые для палеогеографических реконструкций, базирующиеся на связях почвенных свойств с современными условиями, как правило, получены в определенных климатических зонах и для соответствующих геологических пород и отложений, и распространение полученных зависимостей не всегда позволяет однозначно реконструировать климатические особенности для всех исследуемых территорий и отложений. Идеальное решение требует использования в каждом исследовании региональных калибровок, однако такие исследования для территории Русской равнины носят единичный характер. Несмотря на определенные объективные трудности, именно исследование четвертичных палеопочв и отложений с использованием комплекса геохимических, петрофизических и минералогических методов, взаимно дополняющих и уточняющих, позволяет проводить наиболее реалистичные реконструкции условий их формирования. Полученные результаты исследования палеопочв четвертичного периода могут быть использованы в долгосрочных прогнозах будущих изменений степных экосистем юга России при различных сценариях изменения климата.

\section{ФИНАНСИРОВАНИЕ}

Работа выполнена при поддержке Российского фонда фундаментальных исследований (грант № 1929-05178; 19-54-45008).

\section{FUNDING}

The work was supported by the Russian Foundation for Basic Research (grant nos. 19-29-05178; 19-54-45008).

\section{СПИСОК ЛИТЕРАТУРЫ}

1. Алексеев А.О., Алексеева Т.В. Оксидогенез железа в почвах степной зоны. М.: ГЕОС, 2012. 204 с.

2. Алексеева В.А. Микроморфология поверхности кварцевых зерен как индикатор условий леднико- 
вого осадкообразования (на примере бассейна р. Протвы) // Литология и полезные ископаемые. 2005. № 5 (40). С. 420-428.

3. Величко А.А. Природный процесс в плейстоцене. М.: Наука, 1973. 254 с.

4. Величко А.A. К оценке тренда аридизации юга России: по результатам исследований разреза Семибалки-1, Приазовье // Современные проблемы аридных и семиаридных экосистем юга России: Сб. научных статей. Ростов-на-Дону: Изд-во ЮНЦ РАН, 2006. С. 108-133.

5. Величко A.A. Палеоклиматы и палеоландшафты внетропического пространства северного полушария. Поздний плейстоцен-голоцен / Атлас-монография. М., 2009. 120 с.

6. Демкин В.А., Рысков Я.Г., Алексеев А.О., Олейник С.А., Губин С.В. Палеопедологическое изучение памятников степной зоны // Изв. АН. Сер. геогр. 1989. № 6. С. $40-51$.

7. Демкин В.А. Почвоведение и археология. Пущино, 1997. $213 \mathrm{c}$.

8. Демкин В.А., Ельцов М.В., Алексеев А.О., Алексеева T.В. и др. Развитие почв Нижнего Поволжья за историческое время // Почвоведение. 2004. № 12 (37). С. 1324-1333.

9. Демкин В.А., Борисов А.В., Алексеев А.О., Демкина Т.С., Алексеева Т.В., Хомутова Т.Э. Археологическое почвоведение: новые подходы в изучении истории природы и общества // Почвоведение. История, социология, методология. М.: Наука, 2005. С. 324330.

10. Калинин П.И., Алексеев А.О. Геохимический подход к исследованию происхождения лёссовых отложений юго-востока Русской равнины // Вестн. Воронеж. ун-та. Сер. Геология. 2013. № 2. С. 5360.

11. Калинин П.И., Алексеев А.О., Савко А.Д. Лёссы, палеопочвы и палеогеография квартера юго-востока Русской равнины // Труды НИИ геологии Воронеж. ун-та. Вып. 58. Воронеж: Изд-во Воронеж. ун-та, 2009. $140 \mathrm{c}$.

12. Калинин П.И., Алексеев А.О. Геохимическая характеристика лёссовопочвенных комплексов ТерскоКумской равнины и Азовокубанской низменности // Почвоведение. 2011. № 12. С. 1315-1332.

13. Палеогеографические методы исследований. Реконструкция палеогеографических событий и этапов: Учеб. пособие / под ред. И.А. Каревской, А.В. Панина. М.: Географический факультет МГУ, 2012. $200 \mathrm{c}$.

14. Рогов В.В. Особенности морфологии частиц скелета криогенного элювия // Криосфера Земли. 2000. T. IV. № 3. C. 67-74.

15. Рысков Я.Г., Демкин В.А., Мергель С.В., Олейник С.А. Формирование карбонатного профиля темнокаштановой почвы по данным изотопного состава углерода и кислорода // Почвоведение. 1996. № 9 (29). С. 992-998.
16. Рысков Я.Г., Борисов А.В., Рыскова Е.А. Олейник С.А., Демкин B.A. О соотношении педогенных и литогенных карбонатов в степных почвах и закономерности их профильной динамики за последние 4000 лет // Почвоведение. № 3 (32). 1999. С. $263-$ 270.

17. Трофимов В.Т. Лёссовый покров Земли и его свойства / ред. В.А. Трофимов и др. М.: Изд-во Моск. ун-та, 2001. 464 c.

18. Alekseev A.O., Alekseeva T.V., Maher B.A. Magnetic properties and mineralogy of iron compounds in steppe soils // Eurasian Soil Sci. 2003. V. 36. № 1. P. 59-70.

19. Alekseeva T., Alekseev A., Maher B.A., Demkin V. Late Holocene climate reconstructions for the Russian steppe, based on mineralogical and magnetic properties of buried palaeosols // Palaeogeography, Palaeoclimatology, Palaeoecology. 2007. V. 249. P. 103-127.

20. Alley R.B. The Younger Dryas cold interval as viewed from central Greenland // Quat. Sci. Rev. 2000. V. 19. P. 213-226.

21. Cerling T.E., Quade J., Ambrose S.H., Sikes N.E. Fossil soils, grasses, and carbon isotopes from Fort Ternan, Kenia: Grassland or woodland? // J. Human Evolution. 1991. V. 21. № 4. P. 295-306.

22. Gallagher T.M., Sheldon, N.D. A new paleothermometer for forest paleosols and its implications for Cenozoic climate // Geology. 2013. V. 41. № 6. P. 647-650.

23. Gallet S., Borming J., Masayuki T. Geochemical characterization of the Luochuan loess-paleosol sequence China and paleoclimatic implications // Chemical Geology. 1996. V. 133. P. 67-88.

24. Koch P.L. Isotopic reconstruction of past continental environments // Annual Rev. Earth \& Planet Sci. 1998. V. 26. P. 573-613.

25. Krinsley D.H., Doornkamp J.C. Atlas of quartz sand surface textures. Cambridge: Cambridge Univ. Press, 2011. $102 \mathrm{p}$.

26. Mahaney W.C. Atlas of sand grain surface textures and applications. NY: Oxford Univ. Press, 2002. 237 p.

27. Maher B.A., Alekseev A.O., Alekseeva T.V. Climate dependence of soil magnetism across the Russian steppe: significance for use of soil magnetism as a palaeoclimatic proxy // Quat. Sci. Rev. 2002. V. 21. P. 1571-1576.

28. Maher B., Possolo A. Statistical models for use of palaeosol magnetic properties as proxies of palaeorainfall // Global and Planetary Change. 2013. V. 111. P. 280-287.

29. Maher B.A. The magnetic properties of Quaternary aeolian dusts and sediments and their palaeoclimatic significance // Aeolian Res. 2011. V. 3. № 2. P. 87-144.

30. Nesbitt H.W., Young G.M. Early Proterozoic climates and plate motions inferred from major element chemistry of lutites // Nature. 1982. V. 299. P. 715-717.

31. Nordt L., von Fischer J., Tieszen L. Late quaternary temperature record from buried soils of the North American Great Plains // Geology. 2007. V 35. № 2. P. 159-162. 
32. Retallack G.J. Soils of the Past: An introduction to paleopedology. 2nd ed. Malden, USA: Blackwell Science, 2001. 404 p.

33. Sheldon N.D., Tabor N.J. Quantitative paleoenvironmental and paleoclimatic reconstruction using paleosols // Earth-Sci. Rev. 2009. V. 95. P. 1-52.

34. Sheldon N.D., Retallack G.J., Tanaka S. Geochemical climofunctions from North American soils and application to paleosols across the Eocene-Oligocene boundary in Oregon // J. Geology. 2002. V. 110. № 6. P. 687-696.

35. Visser J.N.J., Young G.M. Major element geochemistry and paleoclimatology of the Permo-Carboniferous glacigene Dwyka Formation and post-glacial mudrocks in southern Africa // Palaeogeography, Palaeoclimatology, Palaeoecology. 1990. V. 81. P. 49-57.

36. Vos K., Vandenberghe N., Elsen J. Surface textural analysis of quartz grains by scanning electron microscopy
(SEM): From sample preparation to environmental interpretation // Earth-Sci. Rev. 2014. V. 128. P. 93-104.

37. Wilson M.A. NMR techniques and applications in geochemistry and soil chemistry. NY: Pergamon Press, 1987. $366 \mathrm{p}$.

38. Woronko $B$. Frost weathering versus glacial grinding in the micromorphology of quartz sand grains: processes and geological implications // Sedimentary Geology. 2016. V. 335. P. 103-119.

39. Zech M. Evidence for Late Pleistocene climate changes from buried soils on the southern slopes of Mt. Kilimanjaro, Tanzania // Palaeogeography, Palaeoclimatology, Palaeoecology. 2006. V. 242. P. 303-312.

40. Zech M., Glaser B. Improved compound-specific d13C analysis of n-alkanes for application in palaeoenvironmental studies // Rapid Communications in Mass Spectrometry. 2008. V. 22. № 2. P. 135-142.

\title{
The Mineralogical and Geochemical Parameters Reflecting the Palaeoenvironment of Soil Formation in the South of the East European Plain in Quaternary
}

\author{
A. O. Alekseev ${ }^{1, ~ *}$, P. I. Kalinin 1 , T. V. Alekseeva ${ }^{1}$, and V. A. Alekseeva ${ }^{2}$ \\ ${ }^{1}$ Institute of Physicochemical and Biological Problems in Soil Science, Russian Academy of Sciences, Pushchino, Russia \\ ${ }^{2}$ Lomonosov Moscow State University, Moscow, Russia \\ *e-mail: alekseev@issp.serpukhov.su
}

\begin{abstract}
Reconstructions of the dynamics of soil formation conditions' climatic parameters in Quaternary in the south of the East European Plain are performed. Reconstructions are based on the study of paleosols as indicators of biosphere evolution on the scale of geological and historical time. The completeness and reliability of paleogeographic reconstructions is determined by the selected research objects, including the paleosols of archaeological sites (kurgans) of the steppe zone of the European part of Russia, as well as loess-soil sections of the Azov region, containing a series of Pleistocene paleosols (the last 800 thousand years). Three independent methods were used to perform quantitative reconstructions of paleoenvironment: 1) magnetic method (magnetic susceptibility of soils) linking the soil "magnetic record" with the previous environmental conditions of the steppes and allowing to obtain quantitative climate characteristics (precipitation, aridity) in the Pleistocene and Holocene; 2) geochemical method based on empirical dependencies of geochemical coefficients of weathering, linking changes in the bulk chemical composition of soil mass and its elements with climate factors, as well as a complex of mineralogical studies; 3 ) methods of isotopic geochemistry, the isotopic composition of carbon, allowing us to obtain information about the climate regime of the territory, reconstruct some parameters of climate systems. Based on the obtained set of magnetic, geochemical, and isotopic parameters of soils and rocks, the optimal indicators' set for paleoclimatic reconstructions is proposed. The climatic conditions (paleotemperature, paleoprecipitation, and aridity) of the natural environment of the Eurasian steppes in the Holocene and Pleistocene were modeled.
\end{abstract}

Keywords: evolution of soils, paleopedosphere, global climate change, soil magnetic properties, geochemistry, soil mineralogy

\section{REFERENCES}

1. Alekseev A.O., Alekseeva T.V. Oksidogenez zheleza $v$ pochvakh stepnoi zony [Iron Oxidogenesis in Steppe Soils]. Moscow: GEOS Publ., 2012. 204 p.

2. Alekseeva V.A. Micromorphology of quartz grain surface as indicator of glacial sedimentation conditions: Evidence from the Protva River basin. Litologiya i Poleznye Iskopaemye, 2005, vol. 40, no. 5, pp. 420-428. (In Russ.).
3. Velichko A.A. Prirodnyi protsess v pleistotsene [Natural Processes in the Pleistocene]. Moscow: Nauka Publ., 1973. 254 p.

4. Velichko A.A. Aridization trends in southern Russia according to the studies of Semibakli-1 section (Azov region). In Sovremennye problemy aridnykh i semiaridnykh ekosistem yuga Rossii [Modern Problems of Arid and Semiarid Ecosystems of the Southern Russia]. Rostov- 
on-Don: Yuzhn. Nauchn. Tsentr RAN, 2006, pp. 108133. (In Russ.).

5. Paleoklimaty i paleolandshafty vnetropicheskogo prostranstva severnogo polushariya. Pozdnii pleistotsen - golotsen [Paleoclimates and Paleolandscapes of the ExtraTropical Northern Hemisphere in the Late Pleistocene and Holocene]. Velichko A.A., Ed. Moscow: GEOS Publ., 2009. $120 \mathrm{p}$.

6. Demkin V.A., Ryskov Ya.G., Alekseev A.O., Oleinik S.A., Gubin S.V. Paleopedological analysis of archaeological monuments in the steppe zone. Izv. Akad. Nauk, Ser. Geogr., 1989, no. 6, pp. 40-51. (In Russ.).

7. Demkin V.A. Pochvovedenie $i$ arkheologiya [Soil Science and Archeology]. Pushchino: ONTI NTsBI AN SSSR, 1997. $213 \mathrm{p}$.

8. Demkin V.A., El'tsov M.V., Alekseev A.O., Alekseeva T.V., Demkina T.S., Borisov A.V. Soil development in the Lower Volga area during the historical period. Pochvovedenie, 2004, vol. 37, no. 12, pp. 13241333.

9. Demkin V.A., Borisov A.V., Alekseev A.O., Demkina T.S., Alekseeva T.V., Khomutova T.E. Archaeological soil science: New approaches to the study of the history of nature and society. In Pochvovedenie. Istoriya, sotsiologiya, metodologiya [Pedology. History, Sociology, Methodology]. Moscow: Nauka Publ., 2005, pp. 324-330. (In Russ.).

10. Kalinin P.I., Alekseev A.O. Geochemical approach to the analysis of the origin of loess sediments in the southeastern part of the Russian Plain. Vestn. Voronezh. Gos. Univ., Ser. Geol., 2013, no. 2, pp. 53-60. (In Russ.).

11. Kalinin P.I., Alekseev A.O., Savko A.D. Lessy, paleopochvy i paleogeografiya kvartera yugo-vostoka Russkoi ravniny [Loesses, Paleosols, and Paleogeography of the Quaternary Period in the Southeastern Part of the Russian Plain]. Tr. Nauchno-Issled. Inst. Geol., Voronezh. Gos. Univ., no. 58. Voronezh: Voronezh. Gos. Univ., 2009. $140 \mathrm{p}$

12. Kalinin P.I., Alekseev A.O. Geochemical characterization of loess-soil complexes on the Terek-Kuma Plain and the Azov-Kuban' Lowland. Eurasian Soil Sci., 2011, vol. 44, no. 12, pp. 1315-1332.

13. Paleogeograficheskie metody issledovanii. Rekonstruktsiya paleogeograficheskikh sobytii i etapov: Uchebnoe posobie [Paleogeographic Research Methods. Reconstruction of Paleogeographic Events and Stages: a Study Handbook]. Karevskaya I.A., Panin A.V., Eds. Moscow: Mosk. Gos. Univ., 2012. 200 p.

14. Rogov V.V. Characteristic features of particle morphology in the skeleton of cryogenic eluvium. Kriosfera Zemli, 2000, no. 3, pp. 67-74. (In Russ.).

15. Ryskov Ya.G., Demkin V.A., Mergel S.V., Oleinik S.A. Formation of the carbonate profile of dark chestnut soil according to the isotopic composition of carbon and oxygen. Eurasian Soil Science, 1996, vol. 29, no. 9, pp. 992-998.
16. Ryskov Ya.G, Borisov A.V., Ryskova E.A., Oleinik S.A., Demkin V.A. On the relationship between pedogenic and lithogenic carbonates and their dynamics in the profile of steppe soil during the last 4000 years. Pochvovedenie, 1999, vol. 32, no. 3, pp. 263-270.

17. Trofimov V.T. Lessovyi pokrov Zemli $i$ ego svoistva [Loess Cover of the Earth and Its Properties]. Moscow: Mosk. Gos. Univ., 2001. 464 p.

18. Alekseev A.O., Alekseeva T.V., Maher B.A. Magnetic properties and mineralogy of iron compounds in steppe soils. Pochvovedenie, 2003, vol. 36, no. 1, pp. 59-70.

19. Alekseeva T., Alekseev A., Maher B.A., Demkin. V. Late Holocene climate reconstructions for the Russian steppe, based on mineralogical and magnetic properties of buried palaeosols. Palaeogeogr. Palaeoclimatol. Palaeoecol., 2007, vol. 249, pp. 103-127.

20. Alley R.B. The Younger Dryas cold interval as viewed from central Greenland. Quat. Sci. Rev., 2000, vol. 19, pp. 213-226.

21. Cerling T.E., Quade J., Ambrose S.H., Sikes N.E. Fossil soils, grasses, and carbon isotopes from Fort Ternan, Kenia: Grassland or woodland? J. Human Evolution, 1991, vol. 21, no. 4, pp. 295-306.

22. Gallagher T.M., Sheldon N.D. A new paleothermometer for forest paleosols and its implications for Cenozoic climate. Geology, 2013, vol. 41, no. 6, pp. 647-650.

23. Gallet S., Borming J., Masayuki T. Geochemical characterization of the Luochuan loess-paleosol sequence China and paleoclimatic implications. Chemical Geology, 1996, vol. 133, pp. 67-88.

24. Koch P.L. Isotopic reconstruction of past continental environments. Annu. Rev. Earth Planet Sci., 1998, vol. 26, no. 1, pp. 573-613.

25. Krinsley D.H., Doornkamp J.C. Atlas of Quartz Sand Surface Textures. Cambridge: Cambridge Univ. Press, 2011. $102 \mathrm{p}$

26. Mahaney W.C. Atlas of Sand Grain Surface Textures and Applications. New York: Oxford Univ. Press, 2002. 237 p.

27. Maher B.A., Alekseev A.O., Alekseeva T.V. Climate dependence of soil magnetism across the Russian steppe: significance for use of soil magnetism as a palaeoclimatic proxy. Quat. Sci. Rev., 2002, vol. 21, pp. 1571-1576.

28. Maher B., Possolo A. Statistical models for use of palaeosol magnetic properties as proxies of palaeorainfall. Global Planet. Change, 2013, vol. 111, pp. 280-287. doi 10.1016/j.gloplacha.2013.09.017

29. Maher, B.A. The magnetic properties of Quaternary aeolian dusts and sediments and their palaeoclimatic significance. Aeolian Res., 2011, vol. 3, no. 2, pp. 87144.

30. Nesbitt H.W., Young G.M. Early Proterozoic climates and plate motions inferred from major element chemistry of lutites. Nature, 1982, vol. 299, pp. 715-717.

31. Nordt L., von Fischer J., Tieszen L. Late quaternary temperature record from buried soils of the North 
American Great Plains. Geology, 2007, vol. 35, no. 2, pp. 159-162.

32. Retallack G.J. Soils of the Past: An Introduction to Paleopedology. Malden, USA: Blackwell Sci., 2001, 2nd ed. $404 \mathrm{p}$.

33. Sheldon N.D., Tabor N.J. Quantitative paleoenvironmental and paleoclimatic reconstruction using paleosols. Earth-Sci. Rev., 2009, vol. 95, 1-52.

34. Sheldon N.D., Retallack G.J., Tanaka S. Geochemical climofunctions from North American soils and application to paleosols across the Eocene-Oligocene boundary in Oregon. J. Geol., 2002, vol. 110, no. 6, pp. 687-696.

35. Visser J.N.J., Young G.M. Major element geochemistry and paleoclimatology of the Permo-Carboniferous glacigene Dwyka Formation and post-glacial mudrocks in southern Africa. Palaeogeogr. Palaeoclimatol. Palaeoecol., 1990, vol. 81, pp. 49-57.
36. Vos K., Vandenberghe N., Elsen J. Surface textural analysis of quartz grains by scanning electron microscopy (SEM): From sample preparation to environmental interpretation. Earth-Sci. Rev., 2014, vol. 128, pp. 93-104.

37. Wilson M.A. NMR Techniques and Applications in Geochemistry and Soil Chemistry. New York: Pergamon Press, 1987. 366 p.

38. Woronko B. Frost weathering versus glacial grinding in the micromorphology of quartz sand grains: processes and geological implications. Sediment. Geol., 2016, vol. 335, pp. 103-119.

39. Zech M. Evidence for Late Pleistocene climate changes from buried soils on the southern slopes of Mt. Kilimanjaro, Tanzania. Palaeogeogr. Palaeoclimatol. Palaeoecol., 2006, vol. 242, pp. 303-312.

40. Zech M., Glaser B. Improved compound-specific $\mathrm{d} 13 \mathrm{C}$ analysis of $\mathrm{n}$-alkanes for application in palaeoenvironmental studies. Rapid Commun. Mass Sp., 2008, vol. 22 , no. 2 , pp. 135-142. 